current research now focusing on the earlier Republican phase beneath the building. The identification of the theatre at Aeclanum has aided a better understanding of the organisation of the town, a site also being systematically investigated through geophysics, but the 2018 season has also spread light on the later reuse of the building in the $5^{\text {th }}$ century AD. Elsewhere in Southern Italy two Roman villas are being investigated, the site of Santa Maria della Strada in the Molise (Kay et al.) and the Imperial estate at Vagnari (Carroll) in Puglia. Each of these sites reveal in their archaeological record the impact that the Roman conquest had on these Southern regions.

Archaeological research in Rome has continued at the Archbasilica of St John Lateran (Haynes et al.) where work this past year has been extended north from the baptistery to investigate the Domus Licini Surae, a building identified under the Scuola Infermiere of the Ospedale San Giovanni. At Portus (Keay), the Imperial port of Rome, the focus of the research over the past year has been on the northern mole of the Claudian harbour as well as the Grandi Magazzini di Settimio Severo, in particular a series of structures located immediately to the north of the warehouse complex.

The excavation projects have been complemented by an ever-increasing number of collaborative geophysical and topographical surveys. Over the past year the BSR has supported research at the site of Oricum (Albania) and continued its collaboration with the British Museum at Dangeil (Sudan). The increasing number of international research projects in Sicily encouraged the BSR, together with the Swedish Institute of Classical Studies, the Norwegian Institute in Rome, the Finnish Institute in Rome and the Regione Sicilia to host a two-day conference presenting results from these projects, many of which included geophysical surveys conducted over the years by the BSR. In addition, this year geophysics was conducted by the BSR at the site of Morgantina (on behalf of the Freie Universität Berlin) to investigate the layout of the city around the Hellenistic Northern Baths. Elsewhere the BSR continued to support the work of the University of British Columbia at the late antique villa of Gerace and the investigations of the Swedish Institute of Classical Studies at the Greek archaic site of Francavilla di Sicilia.

STEPHEN KaY

(Archaeological Officer, British School at Rome) s.kay@bsrome.it

\title{
THE LATERAN PROJECT: INTERIM REPORT FOR THE 2018-19 SEASON (ROME)
}

doi: 10.1017/S0068246219000114

The Lateran Project focuses on the archaeology of the Archbasilica of St John Lateran and its immediate surroundings. Preliminary reports have been published in the Papers of the British School at Rome (Haynes, Liverani et al., 2012; 2013; 2014; 2016; 2017; 2018). As in 2017-18, work this year focused on two broad but related zones. The first, the zone exposed beneath the Archbasilica and its adjoining Baptistery, is known for convenience as SGL1. The second zone lies immediately nearby but within the property of the Azienda Ospedaliera San Giovanni-Addolorata. Survey work in this zone, known as SGL2, began in January 2018. Generous support from Mr Peter Smith, including funding for a post-doctoral fellowship at the British School at Rome, held by Thea 
Ravasi, and for the participation of BSR colleagues in field survey has allowed for significant progress in several key research strands.

\section{WORK IN SGL1}

As outlined in the above-mentioned preliminary reports, the Lateran Project has conducted an extensive laser-scan survey underneath the Archbasilica and its adjoining Baptistery since 2012. In 2018 we discovered a way to access the last remaining exposed area of archaeological interest beneath the Archbasilica's floor. This area had been excavated and swiftly planned during a short excavation season in 1977 but can only be accessed today either through a somewhat perilous approach from the deeper scavi or through a hatch in the Archbasilica floor. We are therefore extremely grateful to our colleagues at the Servizi Tecnici del Governatorato Vaticano and to the Chapter of the Archbasilica for granting us access.

Once beneath the floor, we were able to analyse and scan the structural remains. The area is of considerable importance for it not only advances our knowledge of the Castra Nova, containing as it does elements of part of the principia, an adjacent building and the course of an internal road but a stretch of preserved foundation also confirms the easternmost extent of the Constantinian Basilica. To these valuable insights, we may add further observations that reveal the workings of Borromini's engineers, for it is possible to see very directly here the relationship between his reconfiguration of the north aisle and the sub-structures that reconfiguration required.

Thanks to the kindness of our colleagues from the Vatican Museums and the restorers currently actively engaged in the restoration of wall plaster within the main area of exposed excavations, we were also able to deepen our understanding of the decorative scheme employed within the principia of the Castra Nova. This area, already extensively examined by the Lateran Project team, contains the offices and courtyard of the principia. As part of their conservation work here, our expert colleagues have removed a thin black layer of sealant which was applied to the uppermost level of the building's surviving walls when a new ceiling was installed over the excavated area in 1938. This layer had obscured an essential but previously invisible element of the decorative scheme, namely the bottom of the series of lighter coloured panels that had graced the upper section of the wall plaster. As our colleagues have rightly observed, thus understood the overall scheme bears a striking similarity to that which adorned the contemporary Domus Eleniana near the Sessorian palace. The fact that a military headquarters building, albeit one of the emperor's own elite horse guards, should be decorated in such a manner invites us to reflect further on the level of opulence associated with guard units.

\section{WORK IN SGL2}

In SGL2 our work focused on the area within the limits of the historical Ospedale di San Giovanni, property of the Azienda Ospedaliera San Giovanni-Addolorata, excavated by Valnea Santa Maria Scrinari $(1991 ; 1995 ; 1997)$. The Lateran team started working in the Ospedale in 2017 (SGL2: Haynes, Liverani, Ravasi et al., 2018) and between 


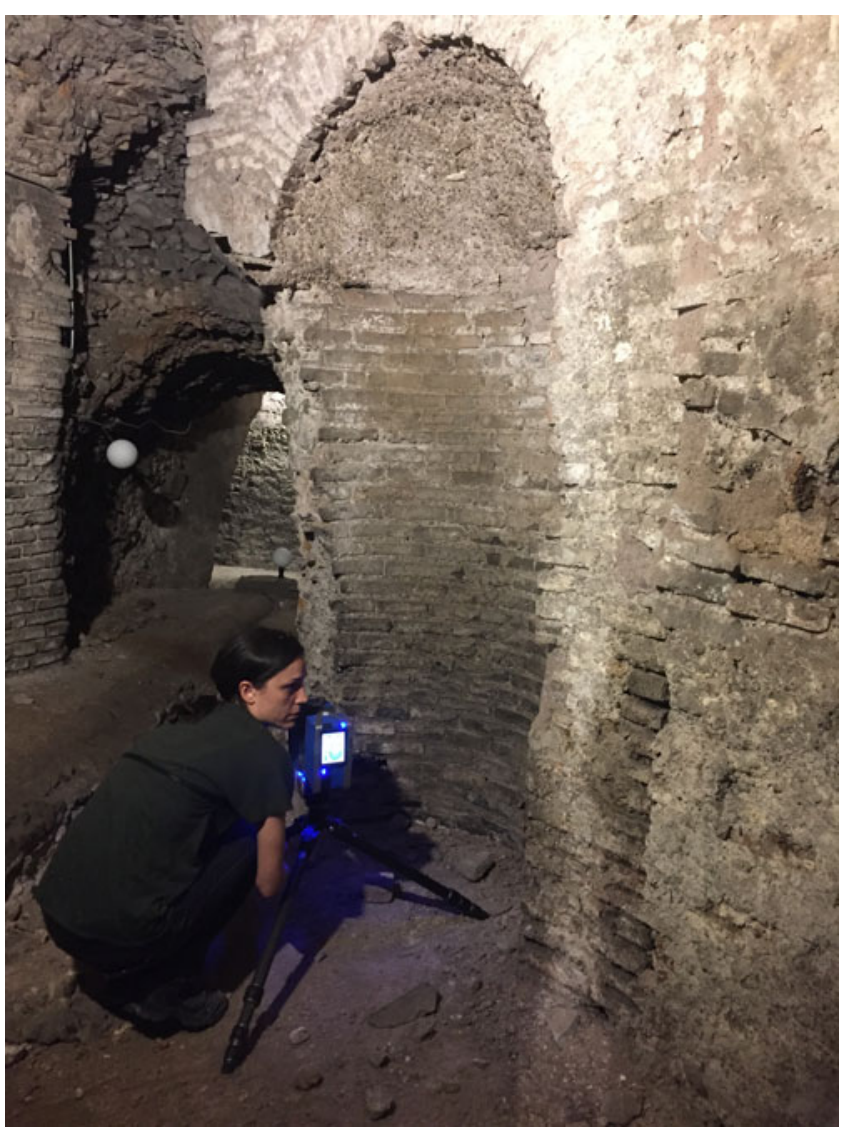

Fig. 1. Beatrice Fochetti sets up the FARO Focus laser scanner prior to recording the Nymphaeum in SGL2 Area 1 (Stephen Kay)

summer 2018 and winter 2019 we completed the laser scan survey and architectural analysis of Areas 1 and 3.

Area 1 was occupied by an elite residence with at least three main phases. Santa Maria Scrinari interpreted these as dating to the $1^{\text {st }}$, the $2^{\text {nd }}-3^{\text {rd }}$ and to the early $4^{\text {th }}$ centuries AD respectively (1995: 191-213), but we are currently reappraising her analysis. Of note is a monumental semi-circular fountain, with alternating semi-circular and rectangular niches, which dates from the earliest phase of the residence (Colini, 1944: 328-9). A significant part of our work in 2018 consisted of the archaeological and architectural analysis of this structure, research which was aided by and articulated through $3 \mathrm{D}$ visualisations of the nymphaeum's original layout and decoration (Fig. 1). The results of this work have been presented at the workshop Rileggere il Laterano antico (Rome, Presidio Ospedaliero San Giovanni, 29 November 2018) and will be published in the proceedings of the workshop.

One of the main issues we face when working on sites exposed by earlier excavations such as those undertaken in Areas 1 and 2 is the fact that those excavations have themselves removed vital evidence - and their documentation of that evidence can be decidedly uneven. In this case, our interpretation of the site is constrained by the destruction of soil stratigraphy by our predecessors and the sometimes-obstructive 
presence of later, additional interventions, such as restoration work carried out since the excavation of the site, that have not been recorded. Beyond the evidence provided by wall stratigraphy and a careful analysis of building design and decoration, the assessment of the chronology of the structures is particularly challenging.

In order to gather all available information, we firstly looked at Santa Maria Scrinari's unpublished reports of the excavations, searching through the records in the Archivio di Documentazione Archeologica in Rome, Palazzo Altemps. ${ }^{1}$ The records are kept in eight boxes (numbers 361 to 368) and contain personal notes, official correspondence, lists of artefacts and several pictures of the sites during and after the completion of the excavations.

Secondly, we decided to tackle wall chronology by examining the building technique, with particular reference to the nature and use of relieving arches (Lancaster, 2007) and the quality of the brickwork. In January 2019 the team carried out a visual assessment and architectural analysis of brickwork and mortar of some of the structures underneath the Lateran Cathedral and the Lateran Baptistery that can be fairly accurately dated, with the aim of comparing them to structures exposed in Areas 1 and 2 of the Ospedale di San Giovanni that are similar in their layout and structural function. The assessment was carried out taking in consideration the presence and ageing of the restoration works and of the structures themselves: after being left exposed to the surface (albeit underground) since the discovery, walls have often developed layers of salt crystallisation that make it sometimes difficult to look at the original surface.

The observation was carried out using a Dino-Lite digital microscope that allows for 200x magnification and portability, a particularly useful feature in underground environments. The visual assessment focused on type, quality and size of tiles and bricks (Lugli, 1957; Bukowiecki, 2010; Serlorenzi, 2017); the quality and thickness of mortar, especially in relationship with the structural function of the wall (Bianchini, 2010: 252-62); the presence of reused bricks and tiles; traces of finishing touches, such as vertical hammering and horizontal polishing on brick surfaces and, finally, the quality of grouting.

The analysis is ongoing and will be completed by the evidence provided by the analysis of $1 \mathrm{~m}^{2}$ portions of the walls from the laser scan recording of the structures (following the model suggested for the analysis of the Aurelian Walls developed by Medri et al., 2016), but preliminary observations permit us to suggest significant analogies between some of the structures in Areas 1 and 2 and the brickwork of some of the structures in the Lateran area, such as the western, external wall of the baths underneath the Lateran Baptistery (dating to the Severan period and likely completed under Caracalla), the southern wall of the principia of the Castra of the Equites Singulares, and the apse of the Constantinian Basilica.

\section{References}

Bukowiecki, E. (2010) La taille des briques de parement dans l'opus testaceum à Rome. In S. Camporeale, H. Dessales, A. Pizzo (eds) Arqueología de la construcción: II. Los procesos constructivos en el mundo romano: Italia y provincias orientales. (Certosa di Pontignano, Siena, 13-15 november 2008). Consejo Superior de Investigaciones Científicas, MadridMérida: 143-51.

1 We wish to thank Ms Luigia Attilia, curator of the Archivio di Documentazione Archeologica for her help and support. 
Bianchini, M. (2010) Le tecniche edilizie nel mondo antico. Dedalo: Rome.

Colini, A.M. (1944) Storia e topografia del Celio nell'antichità. Atti della Pontificia Accademia Romana di Archeologia, serie III, Memorie, 7). Vatican City, Tipografia Poliglotta Vaticana.

Haynes, I.P., Liverani, P., Spinola, G. and Piro, S. (2012) The Lateran Project. Papers of the British School at Rome 80: 369-71.

Haynes, I.P., Liverani, P., Piro, S. and Spinola, G. (2013) The Lateran Project: interim report on the July 2012 and January 2013 seasons (Rome). Papers of the British School at Rome 81: 360-3.

Haynes, I.P., Liverani, P., Piro, S., Spinola, G. and Turner, A. (2014) The Lateran Project: interim report for the January 2014 season (Rome). Papers of the British School at Rome 82: 331-5.

Haynes, I.P., Liverani, P., Peverett, I., Piro, S., Spinola, G. and Turner, A. (2016) The Lateran Project: interim report for the 2015/2016 season (Rome). Papers of the British School at Rome 84: 311-16.

Haynes, I.P., Liverani, P., Heslop, D., Peverett, I., Piro, S., Spinola, G. and Turner, A. (2017) The Lateran Project: interim report for the 2016/2017 season (Rome). Papers of the British School at Rome 84: 317-20.

Haynes, I.P., Liverani, P., Ravasi, T. and Kay, S. and Peverett, I. (2018) The Lateran project: interim report for the 2017/2018 season (Rome). Papers of the British School at Rome 86: 320-25.

Lancaster, L. (2007) The brick relieving arch and urban redevelopment in ancient Rome. In E.M. Steinby, (ed.) Lexicon Topographicum Urbis Romae, 4: 133-44. Quasar, Rome.

Lugli, G. (1957) La tecnica edilizia romana con particolare riguardo a Roma e Lazio. Rome: Bardi. Medri, M., Di Cola, V., Mongodi, S., Pasquali, G. (2016) Quantitative analysis of brick-faced masonry: examples from some large imperial buildings in Rome, in J. DeLaine, S. Camporeale and A. Pizzo (eds), Materials, transport and production. Posters of the 5th International Workshop on the Archaeology of Roman Construction, (University of Oxford, April 11-12, 2015), Arqueologia de la Arquitectura, 13: 1-8. doi: http://dx.doi.org/10.3989/ arq.arqt. 2016.168

Santa Maria Scrinari, V. (1991) Il Laterano imperiale. I., Dalla Aedes Laterani alla Domus Faustae. Rome: Pontificio Istituto di Archeologia Cristiana.

Santa Maria Scrinari, V. (1995) Il Laterano imperiale. II. Dagli Horti Domitiae alla Cappella Cristiana. Rome: Pontificio Istituto di Archeologia Cristiana.

Santa Maria Scrinari, V. (1997) Il Laterano imperiale. III. La proprietà di Licinio Sura e il problema degli acquedotti. Rome: Pontificio Istituto di Archeologia Cristiana.

Serlorenzi, M., Camporeale, S. (2017). Anatomia di un muro romano: dati preliminari sullo smontaggio e quantificazione di alcune strutture in laterizio di epoca adrianea dallo scavo di Piazza Dante a Roma. In G.P. Brogiolo, S. Camporeale, A.C. Arnau (eds) Costi, tempi e metri cubi. Quantificare in architettura. Giornata di Studi (Padova, 28 ottobre 2016), Archeologia dell'Architettura, 22: 21-23.

\section{Ian Haynes, Paolo Liverani, Thea Ravasi, Stephen Kay and Iwan PeveretT ${ }^{2}$}

2 We particularly wish to acknowledge with gratitude the contribution of our colleagues Jon Allison, Beatrice Fochetti, Davide Gangale, Dave Heslop, Denise Heslop and Elena Pomar during the 2018-2019 season. Special thanks are also owing to our generous friends from Roma Sotterranea led by Adriano Morabito for their assistance with access to the cisterns in SGL2. 